\title{
Recent Developments in Pakistan
}

\author{
Javaid Rehman \&t Eleni Polymenopoulou'
}

THE QUESTION OF PRESIDENTIAL IMMUNITY

\section{Introduction}

On the 16th January 2012, the Supreme Court of Pakistan (SC) issued a notice against Pakistan's Prime Minister (PM), Syed Yousaf Raza Gillani to reopen a criminal case against the spouse of a former PM of Pakistan, Benazir Bhutto - and the current President of Pakistan, Asif Ali Zardari. ${ }^{2}$ The notice was drafted by a seven judges Bench under the 2003 Contempt of Court Ordinance (CCO) and referred to an older money-laundering scandal involving both Zardari and his late wife, Benazir Bhutto. ${ }^{3}$ The PM

1 Javaid Rehman is Professor of International Law, Brunel Law School, Brunel University; and member of the Editorial Board, Asian Yearbook of International Law; Eleni Polymenopoulou is Lecturer in Law, Brunel Law School.

2 Vide order dated 16 January 2012 under Section 17(1) of the Contempt of Court Ordinance, following the Appeal on the Criminal Miscellaneous Application No. 486 of 2010 in Criminal Appeal No. 22 of 2002, dated 10 January 2012. In the appeal judgement, the SC had noted a "brazen and blatant failure or refusal of the Federal Government to obey and execute the relevant judgement and directions of this Court the buck stops at the office of the Chief Executive of the Federation, i.e. the Prime Minister."

3 Gillani v. Pakistan, Criminal Original Petition No 06 of 2012, 4 noting that the debate culminated when the former Pakistani Attorney General (himself also involved in scandals) withdrew Pakistan's agreement on providing legal assistance to the Swiss Courts, as a result of what, the proceedings were abandoned. Benazir Bhutto and her husband Asif Ali Zardari had been found guilty in absentia by a Swiss Court of money laundering in 2003, while they were in government. Zardari and Bhutto had been also convicted of similar scandals in the past: e.g., on the 15 April 1999, they had been sentenced by the Lahore High Court to five years in prison, a 8.6 million dollars fine and other measures. See Details of Justice (R) 
did not comply with this judgement ${ }^{4}$ and, on 2nd February 2012, the SC issued an order that a charge be framed against him under the CCO. On the 10th February 2012, the PM challenged this order by filing an IntraCourt appeal, claiming first, the PM's immunity (special privilege) as a matter of law and, second, that there would be a serious danger of political instability if such charges against the President were to be framed. ${ }^{5}$ The SC dismissed the appeal by issuing a 15 page ruling, suggesting that the PM's immunity should be put aside for a number of reasons such as the prevalence of the principle of the rule of law and the principle of citizens' equality as envisaged by Pakistan's constitution and the Islamic religion. ${ }^{6}$ This note discusses this important, yet weak and somehow "flowery" SC order, as being indicative of the tensions in Pakistan between the executive and the judiciary. Moreover, it suggests that the SC delicately avoided judging the vexed question, which was none other than presidential immunity in the light of international law.

\section{Background of the Case}

In 2007, the former Pakistani president, General Parvez Musharraf, created a legal mechanism, the "National Reconciliation Ordinance" (NRO), which enabled selected individuals to escape accountability. ${ }^{7}$ Given that this act had been promulgated in an election year ${ }^{8}$, and that General Musharraf

Malik Muhammad Qayyum, available at http://www.pakistanherald.com/Profile/ Justice-R-Malik-Muhammad-Qayyum-378.

4 The PM proclaimed instead that he would resign if the Supreme Court convicted him under the CCO. See, Will resign if convicted: YousufRaza Gilani, Hindustani Times, 13 Feb. 2012, available at http://www.hindustantimes.com/world-news/ Pakistan/Will-resign-if-convicted-Gilani/Article1-810571.aspx.

5 SC Pakistan, Intra Court Appeal 1/2012 [Against the order dated 02.02.2012 passed by the Court in Criminal Original No. 06/2012] Syed Yousaf Raza Gillani, Prime Minister of Pakistan v. Supreme Court of Pakistan \& another, 10 February 2012, at para. 17.

$6 \quad I d$. at 17 et seq.

7 Gillani, 9.

8 Mainly to benefit one political party; see PILDAT [Pakistan Institute of Legislative Development and Transparency]: Citizens' Group on Electoral Process National Reconciliation Ordinance - NRO 2007, Analysis and the Impact on the General 
claimed its constitutionality by taking measures to make it permanent legislation, the act provoked enormous controversy. ${ }^{9}$

The issue was finally brought before the SC, and with an important judgement at the end of 2009 (Dr. Moshabir Hassan judgement), the SC declared both the Act and Musharraf's measures unconstitutional and non-existent (illegal, mala fide, and void ab initio)..$^{10}$ The present Pakistan Peoples Party government sought to re-examine the case by submitting a "review petition;" however, the SC dismissed this petition with a short order, and declared the NRO judgement "final and binding, including its directives [...] to take immediate steps as ordered."11

\section{Analysis of the Judgement}

The government submitted that the impugned order should be set aside and that both the procedure and the merits should be decided at the case's main hearing. The government advanced three arguments: that there was no "wilful disobedience" of the NRO Judgement; that the government did not benefit from a "full hearing;" and that the impugned order did not cite any reasons in support of its conclusions. ${ }^{12}$ The Supreme Court retorted the following arguments: first, that although the appellant was legally bound to obey the ruling in the NRO Judgement, he admitted his inaction and his "intention not to disobey;"13 second, that the appellant's "factual

Election, Islamabad, 2007, available at http://www.pildat.org/publications/ publication/elections/NROPaper.pdf.

9 The act, which the Parliament also refused to legitimate, granted "amnesty to politicians, political workers and bureaucrats who were accused of corruption, embezzlement, money laundering, murder and terrorism," see, Supreme Court releases detailed judgement on NRO review petition, PAKIsTAN Herald, 16 December 2011, available at http://www.pakistanherald.com/Articles/SupremeCourt-releases-detailed-judgement-on-NRO-review-petition-2928.

10 Dr. Mobashir Hassan \& others v. Federation of Pakistan \& others (2010) PLD (SC) 265 (Pak.). Supra note 4 and also, NRO judgment: Shall it be implemented?, THE Nation, Dec. 2, 2011, available at http://www.pmln.org/media/nd_3810_nrojudgment-shall-it-be-implemented.pmln.

11 Civil Review Petition No.129 of 2010, Nov. 25, 2011, cited in the judgement, 4.

12 Gillani, 6.

13 Id. at 9 7-8. 
defences" could not have been addressed and answered in a preliminary hearing, ${ }^{14}$ and third, that the Court is not required to consider all the facts in depth, rather it has to satisfy itself whether an arguable case exists according to its previous jurisprudence. ${ }^{15}$

Furthermore, and most notably, the government claimed that the PM enjoys immunity from prosecution while in office. Specifically, the PM asked the SC to "show greater restraint and forbearance with respect to a duly elected Prime Minister. ... when the very stability of the democratic system obtained by the people of Pakistan after so much sacrifice, may depend on the outcome of this case." 16

The SC defined this immunity as a "special privilege that accords the appellant preferential treatment by sheltering him from receiving equal treatment in accordance with the law and the constitution and thereby allowing him to disregard the orders of the Court because of his office"17 and deduced that the government "called upon the Court to formulate its opinion, not in accordance with the mandate of law as applicable on the facts of this appeal, but in fear and anticipation of a possible outcome that may flow out of a decision, which may be arrived at by the learned trial Bench on the basis of the law and the Constitution."18

The SC, relying on certain "constitutional imperatives," judged the immunity argument unconstitutional. It advanced, in this respect, four arguments:

\section{A. THE PRINCIPLE OF EQUALITY}

The SC argued that an "exceptionalism" has no constitutional grounds on the equality principle. The latter stems in the judges' view from: a) the Constitution, particularly article 5 ("obedience to the Constitution and law is the inviolable obligation of every citizen wherever he may be...") and article

14 Id. at $99-10$.

15 Imran Ullah v. The Crown, 1954 FC 123 (Pak.) cited in 13.

16 Gillani, 17. However, the immunity seems to have been an explicit argument according to the government $>$ spokesmen. Pakistan court: Zardari corruption case "must be reopened," BBC News, Mar. 8, 2012, available at http://www.bbc. co.uk/news/world-asia-17296602.

17 Id. at para. 17.

18 Id. 
25 ("[a]ll citizens are equal before law and are entitled to equal protection of law"); ${ }^{19}$ and b) Islam. ${ }^{20}$

\section{B. THE FIDUCIARY DUTIES OF THE "CONSTITUTIONAL OFFICE-BEARERS"}

Based on its previous jurisprudence, the SC argued that there is a special constitutional duty of "consciousness" for public officials and politicians. ${ }^{21}$ In this respect, the SC also stressed that article 190 of the Constitution required that "all executive and judicial authorities throughout Pakistan shall act in aid of the Supreme Court." ${ }^{22}$ It also referred to previous politicians' speeches, highlighting that the essence of Pakistan's "Constitutional and democratic dispensation" was based on the rule of law. ${ }^{23}$

The SC cited also, in this respect, another Islamic saying ("The leader of a people is their servant") ${ }^{24}$ along with its previous jurisprudence ("has the absence of the rule of law within the upper echelons and formal structures of the State generated [...] the lawlessness?"), ${ }^{25}$ a 2012 US Supreme Court ruling ("if the government becomes a lawbreaker... it invites every man to become a law unto himself; it invites anarchy" $)^{26}$ and some sage advice of Sheikh Saadi ("if the ruler plunders but five eggs, his minions will plunder a thousand roosters." 27

$19 \quad I d$. at 18.

20 Citing the hadith of Hazrat Umar, a woman from a powerful Arabian tribe was found to have committed theft.

21 "Holders of public office have to remain conscious that in terms of the Constitution 'it is the will of the People of Pakistan' which has established the Constitutional Order under which they hold office. As such they are, first and foremost fiduciaries and trustees for the People of Pakistan [...]" Id. at 24.

$22 I d$. at 24.

23 Such as the former PM Liaqat Ali Khan or Mr. Sirish Chandra Chatapadhaya, citing $i d$. at $24-25$.

$24 \quad I d$. at 26.

25 Sindh High Court Bar Association v. Federation of Pakistan, PLD 2009 SC 879 (Pak.) cited in 28.

26 Olmstead v. US, 277 U.S. 438 (1928) quoted recently by Khosa, J. in Crl. M.A 486 of 2010 in Criminal Appeal No. 22 of 2002 etc. cited in para. 27.

27 Gillani g 28-29. 


\section{THE PRINCIPLE OF THE RULE OF LAW}

A great importance was placed on the link between democracy and the rule of law. Democracy and rule of law are complex subjects and have remained a challenge in the context of a State with political and constitutional history of substantial violations of rule of law, arbitrary rule and endemic corruption. In highlighting the significance of democratic governance and rule of law, the SC noted that "it is the strict adherence to [rule of law], which has fostered the revival of democracy in Pakistan, and upon which its survival still depends" and highlights once more that it was precisely the exercise of the rule of law which was being undertaken by the Trial Court. ${ }^{28}$

\section{THE PRINCIPLE OF DEMOCRACY AND CONSTITUTIONALITY}

The SC made two important statements in respect to democracy and constitutionality, namely that "all state organs and holders of high public office derive their legitimacy from the Constitution" and that "all executive and judicial authorities throughout Pakistan shall act in aid of the Supreme Court." 29 Therefore, in the eyes of the SC judges, the PM, according to the Constitution and especially articles 90 and 204 (which refers to the contempt of Court30), should only act for the benefit of the people of Pakistan, as circumscribed in the Constitution.

For all of the above reasons, the SC dispelled the appellant's claim for privilege and ordered that it will be for the learned trial Bench to decide on the merits of such a plea when it resumes hearing the case, which is for the moment still pending.

$28 I$ Id at 26, citing p 481 of the judgment.

$29 \quad$ Id. at 35.

30 Id. In this respect, the Court says: "[t]he Prime Minister...shall not be answerable to any court for the exercise of powers and performance of functions of [his] office[.]... or for any act done or purported to be done in the exercise of those powers and performance of those functions..." It suggests therefore that even though the appellant is a duly elected Prime Minister and deserves respect, no restraint and forbearance on account of his position can be given. 


\section{Concluding Remarks}

It is indeed remarkable that this time the $\mathrm{SC}$ goes further than the previous NRO judgement Dr. Mobashir Hassan, ${ }^{31}$ raising more reasons for which presidential immunity was invalid. However, there are some weaknesses and incongruities in this decision:

The first of these is that there is no reference to the vexed question, which is the presidential immunity (from the corruption charges and his criminal liability) rather than the government's immunity (from the contempt of court proceedings). The Court deduced only that there is "a prima facie case to be made that the obligation to obey the directions of this Court may have been violated [by the appellant] and that legal scrutiny is clearly warranted." 32

Second, there is no reference either to the academic debate ${ }^{33}$ or to international customary law, ${ }^{34}$ or to comparative law elements with regard to immunity. ${ }^{35}$

Third, the principles enunciated in the judgement do not correspond to specific obligations for the individuals and particularly the Heads of State that could be used in a future case. There is some confusion with respect to the sources of the domestic law, something that raises questions on the interrelation between domestic and international law in Pakistan, between religious and secular law, and, ultimately, the quality of the democracy in this state. Indeed, the SC justifies its decision by all possible means, citing rather selectively its own jurisprudence, the American SC's jurisprudence,

31 Supra note 8.

32 Gillani 28.

33 See Masaya Uchino, Prosecuting Heads of State: Evolving Questions of Venue Where, How, and Why?, 34 Hastings Int'L \& Comp. L. Rev. 341- 385 (2011).

34 It is surprising that the SC does not refer to the extensive ICJ jurisprudence on the issue, especially since the Case Concerning the Arrest Warrant of 11 April 2000 (Congo v. Belg.), 2002 I.C.J. 3, at 5 (Feb. 14).

35 See e.g., $R$ v. Bow Street Metropolitan Stipendiary Magistrate, ex parte Pinochet Ugarte (No 3), [1999] 2 All E.R. 97 (H.L.) (hereinafter Pinochet trial); see Fujimori pleads guilty to bribery, BBC NEws, 28 September 2009, available at http://news. bbc.co.uk/1/hi/world/americas/8279528.stm; Prosecutor v. Charles Ghankay Taylor, Case No. SCSL-03-I, Indictment (Mar. 3, 2003), (hereinafter Taylor's trial in Liberia). 
British academia (HLA Hart), Prophet's sayings on equality and Sheikh Saasi's advice (if the ruler plunders but five eggs). One could also admire the persistence of the Islamic law and hadiths along with the reminding of the value of the Constitution, which expresses the peoples' will. In this respect, it is rather mysterious why the judgement does not even mention binding international legal instruments.

Consequently, the judgement demonstrates some good will, especially by placing the emphasis on the rule of law; the elegant dismissal of the government's political argument of "consequentialism;" the highlighting of the need for transparency in the actual context; and the will that the role of the constitution and the judiciary becomes the people's "arms" vis-a-vis a corrupted government. It shows, however, also a weakness of the Pakistani highest judiciary organ to follow the development of international law, whilst, from a political standpoint, it allows the government to maintain its argument on presidential immunity.

\section{BLASPHEMY LAWS, RELIGIOUS MINORITIES AND THE CASE OF AASIA BIBI}

\section{Introduction}

Aasia Noreen (or Aasia Bibi), a Christian woman living in Pakistan, has become famous worldwide for being condemned to death for blasphemy. ${ }^{36}$ Although the international community has repeatedly called upon Pakistan not to execute the verdict, the appeal before the Supreme Court which has been initiated by her husband is still pending ${ }^{37}$ and Aasia Bibi remains

36 Pakistan's blasphemy laws (Pakistan Penal Code $\$ \$ 295-98$ ) prohibit blasphemy against the Prophet and are applied equally to all religions. These laws came into effect under the military dictatorship of General Zia who adopted a puritanical overview of Islam, and introduced amendments or increased the penalties of the existing blasphemy laws. See e.g., D. Forte, Apostasy and Blasphemy in Pakistan, 10 CONN. J. INT'L L. 27 (1994-95); J. ReHMAN \& S. BREAU, INTRODUCTORY REMARKS IN Religion, Human Rights and International law: A Critical Examination of Islamic State Practices (2007).

37 See Human Rights Commission of Pakistan (HRCP) Report, State of Human Rights in 2010 (2011) at 55, 134 et seq., available at http://www.hrcpweb.org/archive.html; Asia Bibi, Pakistan Blasphemy Case Defendant, Death 
imprisoned. ${ }^{38}$ The impact of this incident has been dramatic since both the Punjab Governor, Salman Taseer and Shahbaz Bhatti, the Christian Federal Cabinet Minister of Minority Affairs, who defended her case and campaigned for the reform of Pakistan's blasphemy laws, were assassinated. ${ }^{39}$

\section{Facts of the Case \& Background}

Mrs. Aasia Bibi was working as a farmhand in Ittan Wali, a village 60 miles west of Lahore. During her work in the fields she was asked by a landlord to fetch water. ${ }^{40}$ She complied, but the other women she was working with - all Muslims - refused to touch the water bowl and drink the water: as it had been touched by a Christian, it was considered to be "unclean." ${ }^{\text {"41 }}$ The incident was forgotten and a few days later, a Muslim mob was initiated in

Sentence Handed Down, Huffington Post, 25 May 2011, available at http:// www.huffingtonpost.com/2010/11/11/asia-bibi-pakistan-blasph_n_782297.html; F. Hassan, Blasphemy in Pakistan, 28 Peace Magazine, Jan. - Mar. 2012.

38 Until Mar. 25, 2012, it has been also reported that Ms. Bibi faces the threat of a suicide attack in jail. See U.N.H.R. Council, Report of the Special RAPPORTEUR ON THE PROMOTION AND PROTECTION OF THE RIGHT TO FREEDOM OF OPINION AND EXPRession, 1753, U.N. Doc. A/HRC/17/27/AdD.1 (MaY 27, 2011) (prepared by Frank La Rue).. See, Frank La Rue, Petition for Asia Bibi on its way to one million signatures, Jan. 20, 2012, http://christiannewsbuzz. com/2012/01/petition-for-asia-bibi-for-release-reaches-half-a-million/ and, Fear for Pakistan's death row Christian woman, BBC News, Dec. 6, 2010, http://www. bbc.co.uk/news/world-south-asia-11923701.

39 Salman Taseer was assassinated by his own guard for defending her case and as a punishment for his campaign to reform Pakistan's blasphemy laws, as it was the case two months later also for Shahbaz Bhatti, the Christian Federal Cabinet Minister of Minority Affairs. See also Navi Pillay, UN Human Rights Chief Condemns Pakistan Assassination, Urges Reform of Blasphemy Laws, Mar. 2, 2011, available at http://www.ohchr.org/en/NewsEvents/Pages/DisplayNews. aspx?NewsID=10784\&LangID=E.

40 J. Perlez, Pakistani Sentenced to Death May Get a Pardon, NY Times, Nov. 22, 2010, available at http://www.nytimes.com/2010/11/23/world/asia/23pstan.html; Christian woman sentenced to death in Pakistan for blasphemy, The Telegraph, Nov.9, 2010, available at http://www.telegraph.co.uk/news/religion/8120142/ Christian-woman-sentenced-to-death-in-Pakistan-for-blasphemy.html.

$41 \quad$ Id. 
Sheikhupura. Mrs. Bibi was taken to the police station, allegedly for her own safety. ${ }^{42}$ Blasphemy charges were subsequently framed against her: she was prosecuted under article 295-C of the Pakistan Penal Code for insulting the prophet and, on the 7 November 2010, she was sentenced to death (hanging) by the local court of Sheikhupura. ${ }^{43} \mathrm{~A}$ few days later, the Lahore High Court (LHC) restrained both the Pakistan President Zardari and the late Punjab Governor, Salman Taseer, from pardoning her or from taking part in any activity aimed at securing pardon for her ${ }^{44}$ Further, on the 6 December, the LHC dismissed a petition that sought a direction to parliament to desist from amending the blasphemy provisions of the Penal Code and confirmed the death sentence ${ }^{45}$ and on the 8 December 2010, Yousuf Quershi, Imam of Mohabat Khan mosque in Peshawar, who gained his notoriety from his incitement to "kill the Danish illustrators," pronounced a reward of Rs. 500,000 for anyone who kills her if the verdict is not applied. ${ }^{47}$ Similarly, the cleric Maqsood Ahmed Masoomi, stated that anyone who commits blasphemy in the village "should be killed on the spot."

\section{Remarks \&t Analysis of the Case}

As noted by the UN High Commissioner for Human Rights, Mrs. Navi Pillay, the case of Bibi and the two assassinations that followed are symp-

$42 \quad I d$.

43 Frank La Rue, supra note 38 at 247, para. 1751.

44 See HRCP Report, supra note 37 at 55, 134 et seq., and also supra note 34.

$45 \quad I d$.

46 Denmark closes Pakistan embassy, BBC News, available at news.bbc.co.uk/2/hi/ south_asia/4725116.stm. J. Klausen, The Danish Cartoons and Modern Iconoclasm in the Cosmopolitan Muslim Diaspora, 2009 Harv. Middle Eastern and Islamic REv. 8, 86-118 (1992).

47 According to HRCP REPORT, supra note 37, Qureshi said, "No president, no parliament and no government has the right to interfere in the tenets of Islam. Islamic punishment will be implemented at all costs [...] We will strongly resist any attempt to repeal laws which provide protection to the sanctity of Holy Prophet Muhammad. Anyone who kills Aasia will be given Rs. 500,000 in reward from Masjid Mahabat Khan [...] We expect her to be hanged and if she is not hanged then we will ask the mujahideen and the Taliban to kill her." 
tomatic of the "pervasive violence against religious minorities in Pakistan and a lack of protection for their places of worship." ${ }^{48}$ Indeed, this case was not a solitary incident. ${ }^{49}$ Although based on a religious identity, Pakistan founder, Mohammad Ali Jinah conceived Pakistan as a modern liberal State, where in minority rights would be fully ensured and protected. However, in modern-day Pakistan, the population is 96 percent Muslim ${ }^{50}$ and religious minorities have historically been subject to discrimination and even prosecuted, as a result of the incremental growth in religious intolerance and religious extremism. ${ }^{51}$ In a country with almost 177 mil-

48 Further, Pillay urged the Government of Pakistan to honour Bhatti and Taseer by supporting their position on the blasphemy laws and she called on the Government to declare a moratorium on application of the blasphemy laws and commission a comprehensive review by independent and impartial experts. See UN Press Release, Pakistan: UN officials condemn assassination of Government minister, U.N. News Centre (Mar. 2, 2011), available at http://www.un.org/apps/news/story. asp? NewsID=37659\&Cr=Pakistan\&Cr1.

49 On other similar blasphemy cases in Pakistan, see Frank La Rue, supra note 38 at 244-46; U.N. Comm'n on H.R., Summary of cases transmitted to Governments and replies received, at 264-76, especially $1212,1254-55$ on the cases of Samuel Masih and Diwan Hashmat Hayat, U.N. Doc. E/CN.4/2005/62/Add.1 (Mar. 30, 2005) (prepared by Theo Van Boven), at 264-76 especially 1212 , 1254-55 on the cases of Samuel Masih and Diwan Hashmat Hayat; Petition for Relief Pursuant to Resolution 1997/50 and 2000/36 submitted by the NGO Freedom Now to the UN Working Group on arbitrary detention for the case of Ayub Masih v. Government of Pakistan, available at www.freedom-now.org/.../Masih-Petition-tothe-WGAD-10.8.01.pdf. See also J. Rehman, Islam, War on Terror and the Future of Muslim Minorities in the United Kingdom: Dilemmas of Multiculturalism in the Aftermath of the London Bombings, 29 Hum. RTs. Q. 831, 831-78 (2007) and generally, I. H. Malik, Religious Minorities in Pakistan, in London: Minority Rights Group International (2002).

50 Preamble of the Constitution of Pakistan, Apr. 12, 1973. According to its Constitution, "Muslims shall be enabled to order their lives [...] in accordance with the teachings and requirements of Islam as set out in the Holy Quran and Sunnah.”

51 As Theodor Gabriel reveals, minorities such as the Christians or the Ahmadis were discriminated against in all aspects of social, political and financial life. See T. Gabriel, Christian Citizens in an Islamic State, cited by S. Shackle, Extreme injustice, New Statesman, Aug. 8, 2011, at 36. 
lion citizens, this 4 percent minority of potential victims represents 7 million people..$^{52}$

In the north and tribal areas of Pakistan, impunity and lawlessness are still today a frequent phenomenon. Minorities, particularly Christians and Ahmaddiyyas, ${ }^{53}$ are increasingly exposed to violence and intimidation from persons "whose mind-set is centred more and more on an extremist form of Islam." ${ }^{\prime 4}$

From an international law standpoint, the efforts of Pakistan to avoid its obligations under international human rights law are striking. This state has one of the worst human rights records, especially those related to religious freedom and women's rights..$^{55}$ Pakistan's pressure within the UN General Assembly and the UN Human Rights Council to make blasphemy laws (i.e., the "defamation of religions") a part of international law is a par excellence indication of this problem. ${ }^{56}$ Even upon the signature of the International Covenant on Civil and Political Rights (ICCPR), Pakistan has

52 This is almost the whole population of Austria or Israel and more than the population of Lebanon or Finland.

53 According to the HRCP, 99 Ahmadis were killed in faith-based violence and at least 64 people were charged under the blasphemy law, including Aasia Bibi. 73 members of religious minority communities committed suicide and 21 attempted it. See HRCP Report, supra note 37.

54 Was Shahbaz Bhatti a Martyr?, AmericA, Mar.21, 2012 at 6, available at www. americamagazine.org/content/signs.cfm?signid $=661$.

55 On the country's record on human rights, see, e.g., the comments issued by the ICERD and the CEDAW Committee and the Human Rights Council: see e.g., U.N. H.R. Council, Communications Report of Special Procedures, at 38, U.N. Doc A/HRC/18/51 (Sept. 9, 2011); also Comm. on the Elimination of Racial Discrimination, 74th Sess., Feb. 16-Mar. 6, 2009, U.N. Doc. CERD/C/PAK/ $\mathrm{CO} / 20$ (Mar. 16, 2009). Indicatively 17: "Notwithstanding the measures taken by the State party such as the amendments of the Criminal Law Act 2004 and the Protection of Women Act 2006, the Committee expresses concern about acts of violence against women, especially those of minority background."

56 See the decades of resolutions which have been promoted within the UN General Assembly and the UN Human Rights Council (and, previously, the UN Commission on Human Rights) at the behest of Pakistan and the Organization of the Islamic Cooperation, after the first one in 1999. See A.G. Belnap, Defamation of Religions: A Vague and Overbroad Theory that Threatens Basic Human Rights, 
expressed reservations in respect of various provisions of the Covenant, to an extent that it is "unclear to what extent the Islamic Republic of Pakistan considers itself bound by the obligations of the treaty and raises concerns as to the commitment of the Islamic Republic of Pakistan to the object and purpose of the Covenant" as noted by the representative of the Netherlands. ${ }^{57}$

Subjected to intense objections from the international community regarding reservations based upon the Sharia and constitutional provisions, and immediately risking the European Union's ineligibility criterion of the European Union's Generalised System of Preferences (GPS Plus Status), on 22 June 2011, Pakistan's Prime Minister, Syed Yousaf Raza Gilani, affected the withdrawal of the majority of Pakistan's reservations to the ICCPR including article 18 , freedom of religion. ${ }^{58}$

The imprisonment and death sentence imposed on Aasia Bibi undermine not only the matrix principles of equality and justice, but also the inherent dignity of the human person itself, all of which are proclaimed in the UN Charter ${ }^{59}$ and the UN Declaration of Human Rights, the international bill of rights ${ }^{60}$ and are by now, an essential part of customary

BYU L. REv. 635-86 (2010); S. Parmar, The challenge of "defamation of religions" to freedom of expression and the international human rights EHRLR 353-75 (2009).

57 Pakistan has expressed reservations with regard to articles 3, 6, 7, 12, 13,18, 19 and 25 of the Covenant. These reservations include the principle of equality between men and women, the right to life and restrictions on the imposition of the death penalty, and naturally, religious freedom, and the competence of the Human Rights Committee to review and comment State periodic reports. The States' reservations on treaties and representatives' comments are generally available at http://treaties.un.org/Pages/ViewDetails.aspx?src=TREATY\&mtdsg_no=IV$4 \&$ chapter $=4 \&$ lang $=$ en $\# 34$.

58 Pakistan decides to withdraw most of the Reservations on ICCPR, UNCAT, The Nation, 23 June, 2011 available at <http://www.nation.com.pk/pakistan-newsnewspaper-daily-english-online/Regional/Islamabad/23-Jun-2011/Pakistandecides-to-withdraw-most-of-reservations-on-ICCPR-UNCAT>.

59 The Preamble of the United Nations Charter (1945) states: "We, the people of the United Nations determined [...]reaffirm faith in fundamental human rights, in the dignity and worth of the human person, in the equal rights of men and women."

60 The Universal Declaration of Human Rights (1948) preamble states that: "Whereas recognition of the inherent dignity and of the equal and inalienable rights of all 
international law. ${ }^{61}$ Her treatment, as both a woman and a member of a religious minority, is in breach of specific human rights proclaimed in a series of instruments that it has ratified and, most notably, the right not to be discriminated against on religious grounds as enunciated in article 4 of the International Convention on the Elimination of All Forms of Racial Discrimination (ICERD). ${ }^{62}$ Her prosecution as such is also contrary to the ICCPR ${ }^{63}$ and especially article 20 para. 2 on the prohibition of incitement to religious hatred and article 26 on the prohibition of any form of discrimination against religious minorities. ${ }^{64}$ Human dignity, freedom and the principle of non-discrimination are such norms, and Pakistan should have international responsibility for human rights violations: not only for not respecting this woman's human rights, but also for ignoring the whole international human rights system itself.

After the ICCPR's ratification, there have been indeed some indications that Pakistan's record on human rights would improve. Likewise, the fact that no "defamation of religions" resolutions passed in 2011 was a blissful surprise.$^{65}$ Many efforts have been deployed in this respect, including those

members of the human family is the foundation of freedom, justice and peace in the world."

61 See, e.g., C. Tomuschat, Human Rights: Between Idealism And Realism (2004).

62 The ICERD was ratified by Pakistan on the 21 Sep. 1966. Bibi's imprisonment as a woman and mother of five children, apart from the religious discrimination she suffered, could also be read as contrary to the CEDAW (ratified by Pakistan on the Mar.12, 1996), according to which "discrimination" should be interpreted in a broad sense ("enjoyment or exercise by women [...] of human rights and fundamental freedoms in the political, economic, social, cultural, civil or any other field.").

63 The ICCPR was ratified by Pakistan on June 23, 2010.

64 See also H. R. Comm., General Comment no. 22 on the right to freedom of thought, conscience and religion (art. 18), g 7-8, U.N. Doc. CCPR/C/21/Rev.1/Add.4, 7-8 (July 30, 1993); H. R. Comm., General Comment no. 23 on the rights of minorities (art. 27 of the ICCPR), 6(1), U.N. Doc. CCPR/C/21/Rev.1/Add.5 (Apr. 8, 1994).

65 In 2011 no "defamation of religions" was voted neither within the UN General Assembly nor within the UN Human Rights Council, supra note 56. See instead the adoption of the more "generic" resolutions, UN Doc. A/HRC/RES/16/18 (Mar. 24, 2011): "Combating intolerance, negative stereotyping and stigmatization of, 
of human rights organizations and UN mandate holders, especially from former UN Rapporteur Asma Jahangir. ${ }^{66}$ However, violence, intolerance, and extremism in Pakistan have not been reduced. ${ }^{67}$ On the ground, any legal or political attempt to reform blasphemy laws results in an impasse. On the one hand, fanatic hate preachers stir up religious hatred, resulting in the perception of fanatics as "heros" for their peers. ${ }^{68}$ On the other,

and discrimination, incitement to violence, and violence against persons based on religion or belief" and also likewise, the UN G.A. Resolution entitled United against racism, racial discrimination, xenophobia and related intolerance A/ RES/66/3 ( Sep. 22, 2011).

66 See e.g., the Special Rapporteurs joint statement (Githu Muigai, Asma Jahangir and Frank La Rue) "Freedom of expression and incitement to racial or religion hatred" OHCHR side event during the Durban Review Conference, Geneva (Apr. 22, 2009). Asma Jahangir has also received the Four Freedoms Award for Freedom of Worship in 2010.

67 HRCP reports that in 2010 "impunity for perpetrators of violence against minority communities continued" and that "little progress was made in bringing to justice those involved in violence and arson targeting an entire Christian locality in Gojra, Punjab in 2009;" see HRCP supra note 37. Likewise, both the UN High Commissioner and the UN Special Rapporteur on Freedom of Expression have noted a rise of extrajudicial killings, abductions and disappearances of minority leaders and political activists in Balochistan province in 2010, noting that 50 such cases had been reported between October 2010 and March 2011; see UN supra note 14 and Frank La Rue supra note 38 para. 1754 and 1756-1757 on other blasphemy cases in 2011. Also, NGOs such as Human Rights Watch report that Sunni militant groups, such as the supposedly banned Lashkar-e Jhangvi, still operate with impunity across Pakistan and violent attacks, including killing, against Shia, Ahmadis, members of the Hazara community and other vulnerable groups is frequent. See Human Rights Watch: World Report 2012 (Pakistan), available at http://www.hrw.org/world-report-2012/world-report-2012-pakistan; see D. Walsh, Salmaan Taseer, Aasia Bibi and Pakistan's struggle with extremism, The Guardian, Jan. 8, 2011, available at http://www.guardian.co.uk/world/2011/ jan/08/salmaan-taseer-blasphemy-pakistan-bibi.

68 See the HRCP REPORT supra note 37; The Hanif Qureshi's sermon which made Mumtaz Qadri to Kill Salman Taseer Gustakh-e-Rasool, available at http://www. wichaar.com/videos/hanif-qureshis-sermon-which-made-mumtaz-qadri-to-killsalman-taseer-gustakh-e-rasool/hanif-qureshis-sermon-which-made-mumtazqadri-to-kill-salman-taseer-gustakh-e-rasool-video_e0c6e14bd.html.; O.B. Jones, 
within a social system which enhances extremist views, it is extremely hard for lawyers to defend a blasphemy case, ${ }^{69}$ as it is for politicians to be opposed to blasphemy laws, ${ }^{70}$ or for judges to issue acquitting judgement in the relevant cases. ${ }^{71}$ It seems, therefore, that alternative advice and reform are necessary, as well as more effective lobbying in order to promote the respect, the protection and fulfilment of women's and religious minori-

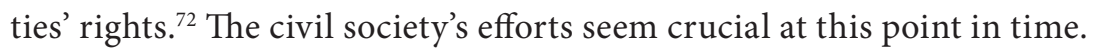

\section{SHARIA LAW \& HUMAN RIGHTS: THE CASE OF MUKHTAR MAI}

\section{Introduction}

On the $21^{\text {st }}$ April 2011, the Supreme Court of Pakistan by two votes against one reversed the Appeal Court's decision that had found the appellants

How Punjab governor's killer became a hero, BBC News, available at http://www. bbc.co.uk/news/magazine-16443556.

69 J. Khan, Death Threats for Asia Bibi's Lawyer and Human Rights Activists, Jan. 7, 2012, http://www.asianews.it/news-en/Lahore:-death-threats-for-Asia-Bibi\%27slawyer-and-human-rights-activists-23630.html; See also From Shaheed Justice Arif Iqbal Bhatti to Shaheed Salman Taseer: PPP's struggle against the Ziaist Blasphemy Law, Jan. 7, 2011.

70 Journalists argue that, after Salman Taseer and Shahbaz Bhatti, the "next on the list" might be the ruling party's legislator Sherry Rehman, who tried to table an amendment to blasphemy laws. D Walsh, Pakistan MP Sherry Rehman drops Effort to Reform Blasphemy Laws, The Guardian, Feb. 3, 2011, available at http://www. guardian.co.uk/world/2011/feb/03/pakistan-blasphemy-laws-sherry-rehman.

71 It is reported, however, that the LHC prosecutor has had some regrets: $D$ Wooding, Asia Bibi's accuser is said to have admitted that his charges are phony, AsIan News, Jan. 22, 2012, http://www.assistnews.net/Stories/2012/s12010128.htm; M. Tossati, 'Strange developments in the Asia Bibi case', http://vaticaninsider.lastampa.it/en/ homepage/world-news/detail/articolo/pakistan-asia-bibi-cristiani-christianscristianos-12175/.

72 See e.g. A. Quraishi, What if Sharia weren't the enemy?: rethinking international women's rights advocacy on Islamic Law, 22 COLum. J. Gender \& L. 1, 173-249 (2010), who argues that a modern apprehension of women's rights in the countries which apply Sharia law should be initiated with the assistance of women activists. 
guilty of the gang rape of Mukhtaran Bibi (or Mukhtar $\mathrm{Mai}^{73}$ ), an incident that had taken place in June 2002, in the Meerwala village in the area of Punjab in North Pakistan. ${ }^{74}$ The judgement provoked the outrage of the international human rights community and is indicative of the failure to guarantee equality and respect for women in Pakistan. ${ }^{75}$

\section{Facts and Background of the Case}

The case commenced when one of the brothers of Naseem-Salma, a girl belonging to the "influential" Mastoi tribe (a branch of the Baloch tribe) reported to the police on the $30^{\text {th }}$ June 2002 that his sister maintained "illicit relations" with Abdul Shaqoor, a 12 year old boy belonging to a "humble family of Gujjar." ${ }^{\prime 6}$ The boy was, in reality, a victim of a sexual assault and

73 Mukhtār Mā"i became a symbol for many women in Pakistan and is now a worldrenowned human rights activist. In 2003, she started the Mukhtar Mai Women's Welfare Organization to defend women's rights and education, especially in the Southern region of Punjab Province (Pakistan) "a region with some of the world's worst examples of women's rights violations, such as rape, gang rape, domestic violence, honour killing, vani (exchange of women in settling the disputes), forced and child marriages." Mukhtar Mai has also won the North-South Prize from the Council of Europe, see, MUKhtar MaI WOMEn's Organisation, http://www. mukhtarmai.org.

74 Supreme Court of Pakistan: State v. Abdul Khaliq and others (Criminal Appeals No.163 to 171 and S.M. Case No.5/2005). See also U.N. C.H.R., Report of THE Special Rapporteur on violence against women, 151 , U.N. Doc. E/ CN.4/2003/75/AdD.2 (JAN. 14, 2003) (PREPARED by RADHIKA COOMARASWAMY). See also, U.N. H.R. Council, Report of the Special Rapporteur on torture AND OTHER CRUEL, INHUMAN OR DEGRADING TREATMENT OR PUNISHMENT, U.N. Doc. A/HRC/13/39/Add.1 (Feb. 25, 2010) (prepared by Manfred Nowak). See also Reuters, Pakistan court acquits suspects in Mukhtaran Mai case, DAWN. сом, Apr. 11, 2011, http://www.dawn.com/2011/04/21/supreme-court-upholdslhc\%E2\%80\%99s-verdict-in-mukhtaran-mai-case.html.

75 See Siobhan Mullally, Women, Islamisation and Human Rights in Pakistan, in Religion, Human Rights And International Law: A Critical Examination Of Islamic State Practice 379-408, especially 405 et seq. (Javaid Rehman \& Susan C. Breau, eds., 2007). 
sodomy by these men. ${ }^{77}$ One week earlier, on the $22^{\text {nd }}$ June 2002 , a tribal council had been conveyed (panchayat), with the participation of another two of the Mastoi tribe as "arbitrators." The latter had also obliged the boy to stay confined in their house as a punishment for his alleged "illicit relations," something which would allow the family to continue the boys' sexual harassment with the panchayat's blessings. ${ }^{78}$

As a remedy for these alleged "illicit relations," the panchayat, without conducting any kind of investigation, allegedly ordered "exchange marriages" to be arranged between the brothers of Naseem and Shaqoor's sister, Mukhtaran Bibi, something that is a common practice in the village. ${ }^{79}$ However, the arbitrator who was acting on behalf of Shaqoor declined the offer and Mukhtaran Bibi went, according to the village's tradition, to visit the Mastoi house and seek forgiveness for her brother. ${ }^{80}$ During this visit, a gang rape (Zina-bil-jabr) was committed against her. ${ }^{81}$

Mukhtaran Bibi accused 14 men of being involved in her raping and in 2002 an investigation took place. The 14 men were led to the police and charged with the offences described in the relevant legislation (i.e., Sections

77 During the trial, Shaqoor denied the fact that he had illicit relations with Naseem and claimed that he was sodomized by one of her brothers and the two other men acting on behalf of the Mastoi family during the panchayat. This claim was also the object of a debate during the proceedings ( 17 et seq.), despite the fact that the doctors noted that "a positive report of sexual intercourse was produced."

78 Abdul Khaliq, supra note 74, at 9 4-5.

79 Also, interestingly, some of the witnesses of the case (e.g., Witness no. 13, 21) submitted that the panchayat commanded that ziadati be committed with Mukhtaran May. Such an atrocity is a common practice in this area of Pakistan. Moreover, it is expected that the woman who is the victim is killed afterwards or commit suicide, again in order to preserve the honour of the male members of the two families involved. In general on the women's situation in the tribal areas, see Rebecca Conway, Rape, mutilation: Pakistan's tribal justice for women, Reuters, Aug. 12, 2011, http://www.reuters.com/article/2011/08/12/us-pakistanwomen-idUSTRE77B63I20110812, and Waheed Khan, Pakistani rape victim says attacks increasing, ReUTERs, Feb. 1, 2007, http://uk.reuters.com/article/2007/02/01/ idUKISL9288020070201.

80 Abdul Khaliq, supra note 74, at, 2-3: "all dragged her into the room of Khaliq's house, where zina- bil-jabbar was committed with her by all of them.” Id. at 4-5. Id. 
19(4), 11 of the Offence of zina (Enforcement of Hudood) Ordinance VII of 1979, combined with Section 149, 354-A ${ }^{82}$ and 109 of the Pakistani Penal Code and under Sections 10 and 7(c) of the 1997 Anti-Terrorism Act). ${ }^{83}$ The Anti-Terrorist First Instance Court hence sentenced the six men to death and acquitted the other eight citing a "lack of evidence" and the benefit of Section 382-B Pakistani Criminal code. ${ }^{84}$

The judgement of this Court was challenged before the Lahore High Court(LHC) by both parties. Five of the six men were acquitted of all charges citing a lack of evidence and advancing a number of reasons. ${ }^{85}$ Only one man's conviction was upheld, converted, however, from Section 10 paragraph 4 of the Ordinance to Section 10 paragraph 3 (reducing the capital punishment from death to life imprisonment). ${ }^{86}$ The SC judgement said that the LHC had provided sufficient proof, noting that the HC's con-

82 The article 354-A is entitled "Assault or use of criminal force to woman and stripping her of her clothes" says that "whoever assaults or uses criminal force to any woman and strips her of her clothes and in that condition, exposes her to the public view, shall be punished with death or with imprisonment for life, and shall also be liable to fine."

83 Article 6(c) of the Terrorist Act states that: "A person is said to commit a terrorist act if he, (c) commits an act of gang rape, child molestation, or robbery coupled with rape as specified in the Schedule to this Act." On 1 September 2002, the antiterrorism Court in Punjab decided that six of the fourteen accused had "conveyed Panchayat, mostly of their Mastoi Baluch tribe of the area, along with others [...] and coerced, intimidated, overawed the complainant party, and the community; created a sense of fear and insecurity in society; and thereby committed the [related] offences."

84 State v. Abdul Khaliq, supra note 74 , at 5.

85 Among the reasons cited: "sole testimony of the prosecutrix to prove the occurrence, no one else had seen it and hence is insufficient to establish the guilt of the accused;" "the DNA and SEMEN tests were not conducted to prove the gang rape;" "there are contradictions and inconsistencies in the statements of the witnesses inter se and also with their previous statements;" "the occurrence has not taken place in the manner as is stated by the PWs;" "there are no significant marks or injuries on the body of the prosecutrix, which is very unusual in [a case of this kind]." 
clusions "should [generally] not be upset, except when palpably perverse, suffering from serious and material factual infirmities." ${ }^{87}$

Consequently, the SC found no error in the application of the law, opining that the "factual conclusions" of the LHC "[did] not suffer from any factual or legal vice." ${ }^{88}$ In this respect, it agreed with the appreciations of the Lahore Court in all points related to the procedure ${ }^{89}$ and dismissed the appeal. ${ }^{90}$

\section{COMMENTS ON THE SUPREME COURT'S JUDGEMENT}

The Supreme Court's decision raises a number of questions, which can be only succinctly addressed here and which mark a long way for the judiciary's fight in the building of a better human rights record. It is optimistic however to note that most of these points are raised by Justice -Nasire ul-Mulk in his 36 pages dissenting opinion.

\section{a. Incompatibility of the Islamic system of proof with human rights law}

The Quran provides for a strict and rigid system of proof, incompatible with human rights law. The syllogism followed by the SC was based on a lato-sensu presumption of innocence for the accused rapists (paragraphs 17-31), something that makes particularly difficult to produce proof in cases regarding both violence and the most intimate sphere of a person.91 It this respect, the CS could have also advanced previous jurisprudence of

87 Id. at para. 15. Following several arguments on the version of the truth (5-17), the SC observed that "the foundational facts of the case [...] make the prosecution version implausible, flimsy and un-canny as set forth.” ( 20).

Id. at 22 .

89 E.g., the Court admitted that the delay of a lodging of a complaint by a rape victim is fatal to the prosecution or the fact that the testimony of a rape victim is not sufficient in a rape case.

$90 \quad$ Id. at 99 26-34.

91 This point is observed correctly only by the dissenting judge Nasir-ul-Mulk who highlighted that the High Court had erred in holding that the delay in lodging of F.I.R. was fatal to the prosecution case and insisted on the fact that in such cases there is no need that the testimony of the rape victim is corroborated. In this respect, Justice Ul-Mulk cited a number of related judgements of both the 
international instances, such as the European Court of Human Rights 92 and the Committee Against Torture (CAT).93

\section{b. Incompatibility of the zina offense, in particular, with human rights law and procedural guarantees}

Under Islamic law, any extramarital intercourse constitutes the Islamic sin of zina (illegal adultery). ${ }^{94}$ An unproved imputation of zina is in itself a had offense, sometimes punishable by lashes, or even by lapidation (although the latter is not explicitly stated in the Quran). ${ }^{95}$ However, this kind of understanding and interpretation of sexual relations and this system of proof have extremely damaging consequences, since a rape (which is a zina) would remain unpunished (since it is improbable to have four eye-witnesses), whereas a sexual intercourse of two adolescents (which is also a zina) could

Pakistani and the Indian Supreme Court. See para. 19-20 and 35 of the dissenting opinion.

92 The European Court has (1) assimilated rape with torture in specific cases as provoking a serious and inhuman treatment and (2) in assessing both written and oral evidence, the Court generally applies a "beyond a reasonable doubt" rule: "Such proof may follow from the coexistence of sufficiently strong, clear and concordant inferences or of similar unrebutted presumptions of fact (see, e.g., Ireland v. United Kingdom, App. No. 5310/71, 2 Eur. H.R. Rep. 25 (1978); Ilascu and Others v. Moldova and Russia, App. No. 48787/99, 40 Eur. H.R. ReP. 46 (2004); more recently, Zontul v. Greece, App. No. 12294/07 (2012).

93 General Comment no. 2, CAT/C/GC/2, (Jan. 24, 2008) points 10-11: “in comparison to torture, ill treatment differs in the severity of pain and suffering and may not require proof of impermissible purposes;" See also a multiple rape case, V.L. v. Switzerland, CAT 262/2005 (Nov. 20, 2006).

94 Islamic law disposes for six hadd offenses theft, rebellion, illicit sexual intercourse, apostasy, the consumption of alcohol (wine: sharb al khamr), false accusation or unlawful sexual intercourse (qudf). See Mashood A. BAderin, InTERNATIONAL Human Rights And Islamic Law, 79 et seq. (2005); Nisrine Abiad, Sharia, Muslim States And International Human Rights Treaty Obligations: A Comparative Study (British Institute of International and Comparative Law, 2008).

95 See Noel J. Coulson, Regulation of Sexual Behavior under Traditional Islamic Law, in Society And The Sexes In Medieval Islam 63-68 (Afaf Lufti Al-Sayyid Marsot, ed.,1979). 
be punished by a violent physical assault (lashes) or death (lapidation). One should equally note that the repression of sexual tendencies as well as the extreme repression of sexuality (including homosexuality ${ }^{96}$ ) in the context of Islamic states such as Pakistan, naturally has extreme consequences, such as sexual assault and rape, as in the present case.

\section{c. Incompatibility of Some Traditions in Pakistan and Particularly the Panchayat Institution with Pakistan's Human Rights Obligations}

There is some confusion in the judgement with regard to the place of tribal justice, and especially tribal practices such as the panchayat, which are contrary to human rights standards. The Supreme Court does not explicitly condemn the panchayat, even though this institution, subject to an extreme "patriarchal mindset," is a per se violent institution against women, which applies harsh and partial tribal laws, and does not represent any standard of "fair justice," as it is shown in the present case. ${ }^{97}$

\section{d. Incompatibility of Islamic Law with Human Rights Law with Respect to Zina, "Illicit Relations" And Marital Rape Of Girls Over 12 (Which is Allowed According to Pakistani Laws)}

At the time of the incident, Mukhtaran Bibi was 16 year old and her brother 12 year old. Pakistan failed to protect both of them and there is not a single reference to human rights in the judgement. The fact that an "exchange

96 The Quran provides that a zina offense should be brought before a Court only when it is committed in a shameless and immodest way and there are four witnesses for it, while in all other cases, zina is not punishable by a Court. Further, as to male to male sexual intercourse in particular, in contrast with the Quran, which is (supposedly) hostile against homosexuality, and in contrast with several conservative Islamic scholars, this is an extremely common, yet extremely restricted, practice in several areas of South Asia, not acknowledged as such and punishable sometimes by death. See e.g., Khaled El-Rouayheb, Before Homosexuality In The Arab Islamic World, 1500-1800 (University of Chicago Press, 2005); Islam And Homosexuality, Vol 2 (Samar Habib ed., Greenwood, 2010).

97 This point of view is also supported by I Ahsan. See, Irum Ahsan, Panchayat and jirgas (lok adalats): Alternative Dispute Resolution System in Pakistan, in Strengthening Governance Through Access To Justice, 27, 27-37 (Amita Singh \& Nasir Aslam Zahid, EDS., 2009). 
marriage," i.e., a gang rape of a 16 year old girl is allowed under tribal and national laws in Pakistan, ${ }^{98}$ especially under the panchayat pretext to "seek forgiveness," is an extreme violation of human rights law in the light of the UN human rights charter, the UDHR, the recently ratified ICCPR, the ICERD (non- discrimination is included within the definition of discrimination, since it prohibits acts when carried out for "any reason based on discrimination of any kind...") and both the CEDAW and the CRC.

\section{e. Disregard for Women, Children's Rights, and for the Human Rights International System And Civil Society}

The fact that the SC disregarded the facts of a case of a woman against whom the SC itself acknowledges that "a blatant, heinous and untoward incident" took place, who herself became a symbol of the human rights struggle and for whom the international community of activists raised 1 million of signatures, is per se a flagrant disrespect for women's value and rights, as proclaimed, for example, in article 4(c) of the UN GA Declaration on the Elimination of Violence against Women. ${ }^{99}$ Judged at a public hearing (as opposed to a doors closed), with the rapists present and with Mukhtar Mai's own absence, is inevitably also indicative of the failure to preserve a person's right to privacy in the par excellence most intimate aspect of one's private life. ${ }^{100}$ In issues regarding to women's and children's rights there is unfortunately a long way to go for Pakistan to comply with international human rights law. For the moment, the hope is to be found in the judicial activism, and in the personal ethos of selective judges, who accomplish their mandate without fearing reprisals from religious extremists.

98 In Pakistan, marital rape is recognised only when the girl (wife) is under 12 years according to section 376 of the Penal Code (imprisonment for maximum 2 years and fine). See also, the World Organisation Against Torture, Rights of the Child in Pakistan, Report on the implementation of the Convention on the Rights of the Child by Pakistan, prepared for the Committee on the Rights of the Child (34th sess. - Geneva, Sept. 2003), available at www.juvenilejusticepanel.com/.../ OMCTAltRepRChildPakistan03EN.

99 Declaration on the Elimination of Violence against Women, G.A. Res. 48/104, U.N. Doc. A/RES/48/104 (Feb. 23, 1994).

100 The judgement itself is a breach of Mukhtar Mai's intimacy, characterizing her: "an unmarried virgin victim of a young age, whose future may get stigmatized." 